\title{
FOSSILIZATION, COMMUNICATIVE RATIONALITY AND COMMUNICATION STRATEGIES IN SECOND LANGUAGE LEARNING
}

\author{
Zhanna Vavilova ${ }^{1}$, John T. Broadbent ${ }^{2}$ \\ ${ }^{1}$ Kazan State Power Engineering University \\ 51, Krasnoselskaya Str., Kazan, Russia, 420034 \\ ${ }^{2}$ Professional Education for Academic Requirements (PEAR) Academy \\ 2/127, Rundle Mall Level, Adelaide, Australia, SA5000
}

\begin{abstract}
Fossilization was first defined in 1972 as a failure, or an ultimate attainment in adult second language acquisition that falls short of native-speaker competence. It represents a final stage in the interlanguage development of the individual learner and characterizes all but a very few adult second language learners.

Over the 40 years or so since the term appeared, fossilization in adult second language acquisition has come to be widely accepted by scholars as a genuinely existing phenomenon. Fossilization is now viewed as permanent and resistant to correction either through instruction or acculturation. However, no universally accepted definition or explanation of fossilization has achieved universal acceptance.

This paper attempts to add an extralinguistic perspective on fossilization and its possible outcome in the communicative practice of adult L2 speakers by building a bridge between linguistics and teaching languages, on the one hand, and philosophy of communication, on the other. Habermasian concept of communicative rationality is applied to demonstrate that oratory and writing skills ensure a more significant role in a dialogue, which seems to be sufficient grounds for fighting fossilization.

In terms of the theory of speech acts, the paper attempts to trace the mechanism of fossilizing in a transition from the inner space of an individual consciousness and intent (illocution) to the outer space of the perlocutionary consequence when a locutionary distortion of the speech itself does not affect the speaker's intent and he / she receives no feedback of the error made. Several factors inhibiting the effectiveness of such corrective feedback are touched upon, as well as certain strategies adopted by second language learners in their communicative efforts.
\end{abstract}

Key words: Fossilization, Second language learning, Communicative rationality, Communication strategies, Speech acts theory

\section{FOSSILIZATION: BACKGROUND AND CURRENT ISSUES}

Fossilization in adult second language acquisition was first defined by Larry Selinker in 1972, as an ultimate attainment in L2 acquisition that falls short of nativespeaker competence [1]. The acquired language ceases developing and fossilizes into an interlanguage. In that respect, it stands in stark contrast to child L1 acquisition which is almost universally entirely successful where success is defined as total mastery of the target language. Fossilization represents lack of mastery of the target language despite continuous exposure to it, motivation to succeed and opportunity for practice. However, it has been pointed out that each individual learner's ultimate attainment is unique to them. It may include native-like competence in some aspects of L2, but not 
in others. Failure is therefore differential between learners - even learners sharing similar or identical learning circumstances; and also within learners - total mastery in some respects, but falling short in others.

Over the 40 years or so since Selinker first coined the expression, fossilization in adult second language acquisition has come to be widely accepted by linguists as a genuine and universal phenomenon. Apart from gaining this recognition, acceptance of the reality and persistence of fossilization has prompted some advance in understanding and responding to the diverse manifestations of ultimate attainment in L2 acquisition. Conceptual frameworks have been proposed, within which to understand works on fossilization, backed with a collection of empirical and analytical studies that help ameliorate both the definitional and empirical shortcomings of contemporary fossilization research [2]. The phenomenon is undergoing elaboration, with various allotypes distinguished - for instance, a term 'pragmatic fossilization' has been introduced to define the inability to use discourse markers that may bear little semantic load but help to sustain the flow of a conversation [3].

However, in the years that have elapsed since Selinker introduced the notion, there has not been much uniformity in defining and interpreting fossilization and therefore explanatory accounts have been widely disparate, leading to more confusion than clarity in the literature with some researchers associating fossilization with slow-learning; others connecting it to habitual errors; some seeing it as an empirical phenomenon, others as an explanation for other learning phenomena [2]. Without an agreed definition of fossilization, and therefore understanding of what this persistent lack of mastery of L2 language means, it is hard to see how second language acquisition theory can make any progress in this area.

Taking into consideration that for the moment idiosyncratic perspectives on fossilization persist, it appears important to unite them within a framework that would be able to encompass several linguistic models. Speech act theory as well as the concept of communicative rationality seem to be able to provide such basis to make it possible to view fossilization not as a strictly linguistic phenomenon related to teaching and learning languages but as one of the elements of the communicative process in crosscultural settings.

\section{FOSSILIZATION IN THE LIGHT OF COMMUNICATIVE RATIONALITY}

Viewed from an extralinguistic social perspective, linguistic processes make up the technologies of social interaction. At the root of Jurgen Habermas's universal pragmatics lies a model of linguistically mediated interaction regulated by norms in a certain community [4]. His approach may be applied to explain the principles of symbolic reproduction of the 'lifeworld', that is, the individual's linguistically shaped cognitive horizon, based on practices and assumptions that are very much taken for granted in a certain social group. As far as transmitting this lifeworld to a member of another group is concerned, the notion of linguistic mediation should be studied more carefully, especially if it is a matter of cross-linguistic communication. If we often fail to understand a friend, a colleague, a relative — someone who belongs to our circle - 
what kind of understanding can we hope for in speaking to a foreigner, when one or both of the interlocutors lack competences acquired through the processes of language learning and socialization and thus have difficulty in comprehension or expression?

Habermas put forward the idea of replacing the paradigm of knowledge of objects with that of mutual understanding between subjects [4]. Bringing this idea into the realm of language use, the knowledge of phonological and grammar correctness cedes to communicative competence and attainment of one's communicative goal, that is the achievement of mutual understanding. It is true that instrumental rationality - phonological and grammatical correctness - may be viewed as necessary to achieve effective interpersonal linguistic communication. As Hymes put it, it is not just knowledge, but an ability to use it effectively that makes up one's competences [5]. However, it is surely simplistic to see fossilization merely in terms of lack of knowledge and competence and, in this respect, a cause of considerable communicative disruption and failure, at least on the interpersonal level. In fact, L2 learners may even be able to communicate successfully for their immediate purposes, that is achieve certain instrumentality, but also achieve an even higher level of communicative competence. In her study, R. Shapira describes a case of Zoila, a young Spanish-speaking woman, a Guatemalan immigrant into the USA, whose process of L2 acquisition seems to have been totally arrested at a fairly rudimentary stage and showed no evidence of development over the three years that she was the subject of study, not just because she passed a certain age of natural language acquisition, but to a great extent because she developed necessary skills to be able to communicate for living [6]. The author argues that since Zoila had an instrumental rather than integrative motivation, her performance had reached a certain point at an elementary stage in the process of language acquisition which satisfied her needs but had not improved since. Once she reached her immediate goal in her daily communicative practices, she made no further attempts to improve her language performance.

Going back to the concept of communicative rationality, good oratory and writing skills lead to a better argumentation and ensure a more significant role in a dialogue than a mere wish to be understood. In which case, advanced L2 learners have a better claim in the Habermasian dialogue, however inclusive it is supposed to be. Still, in practice, L2 learners are often content with their performance, especially if, unlike Zoila, they are not exposed to the target language outside the classroom.

In terms of the theory of speech acts which was also applied by Habermas to substantiate his communicative rationality concept, we may trace the mechanism of fossilizing in a transition from the inner space of an individual consciousness and intent (illocution) to the outer space of the perlocutionary consequence when a locutionary distortion of the speech itself does not affect the speaker's intent and he / she receives no feedback of the error made. Though it was initially applied to explain illocutionary forces employed by speakers of a linguistic community [7], the same criterion of achieving conditions of satisfaction may be applied when analysing communicative practices between speakers of different communities. Condition of satisfaction is a criterion of successfulness of speech which is here related to an adequate receiver's reaction, rather than to achieving grammatical or phonological correctness of the utterance. 
The importance of teaching how to manage speech acts has become salient ever since the competence approach started replacing the cognitive paradigm. Speech acts in second language teaching became not merely a subject of study or an aim to be achieved; they comprise certain patterns that organise the teaching process itself. For the study of fossilization, feedback as an element of a speech act, is especially important, for it is not just an indicator of pragmatic success, but a crucial factor having a certain impact on language attainment.

If the feedback contains a certain correction of the statement that bears an error or a mistake, it may serve as an instruction for the L2 learner. However, not every instructive feedback serves to tackle fossilization [8. pp. 72-73]. It is another point about fossilization that needs further research. Profound differences of opinion exist as to the effectiveness of correction in averting fossilization in L2 acquisition. Among the factors inhibiting the effectiveness of correction could be the following:

(a) inconsistency on the part of L2 teachers in identifying and drawing attention to errors and in the form of correction they apply;

(b) the teaching materials used;

(c) inter-student talk - which will be in varying levels and forms of interlanguage and likely to be as influential in the development of individuals' interlanguage as the model provided by the L 2 teacher;

(d) the linguistic competence of the teacher, especially if he / she is not a nativespeaker of the target language;

(e) the teaching strategies employed;

(f) the opportunities that exist outside the classroom for practising the target language.

It might appear that the best kind of feedback is one indicating that the speaker has been understood, but at the same time providing the correct pattern or pronunciation for the same utterance. However, in the classical study cited above, while the student is sensitive to the subject and mood of the conversation, she is not at all sensitive to the language model that the native speaker provides. On the contrary, the researcher adapts her own speech to match that of the learner while the learner is providing the model for the native-speaker's speech.

Zoila: Do you think is ready?

Shapira: I think is ready.

Zoila: Why she's very upset for me?

Shapira: S. is upset for you?

Zoila: Yeah, is [6. p. 247].

This often happens in places where a language may fossilize into a genuine creole, on the level of whole communities, and not just into an idiolect, on the level of an individual language learner. As long as all members of communities share this language variety, each one having a better opportunity to achieve their communicative goals through its use, fossilization persists. For instance, in Malaysia, where 'Manglish', a kind of creole, is a normal form of discourse both between and within the different racial groups that make up the majority of Malaysian society - Malay, Chinese and Indian, 
the L1 model of English used by expat native English speakers is hardly ever adopted by locals. Instead, English speakers commonly and quickly adopt the speech-model of Manglish which became a communicatively more successful option for this specific setting than "standard" English. It has become a kind of friendly patois even among those who would be expected to follow all norms and standards of English, e.g. English teachers who live and work in Malaysia. These adjustments can be viewed as steps towards the mutual understanding and dialogue argued for by Habermas. In intercultural communication, it is not only the task of L2 speakers to turn their illocutionary force towards a pragmatic outcome. It is also a challenge for native speakers to be able to understand them, thus overcoming the other's fossilization.

\section{COMMUNICATIVE STRATEGIES IN SECOND LANGUAGE LEARNING}

To demonstrate the points made in this paper, conversation analysis was applied as a tool of verbal interaction research in naturally occurring linguistic environments. The data for the analysis have been gathered during the years of the authors' language teaching practice.

The transcripts of conversations have been analyzed and relevant to the study extracts have been classified according to Ellen Bialystok's taxonomy of communication strategies that are commonly adopted by second language learners in their attempts to convey ideas and information for which they have insufficient (L2) language [9]. Her discussion of communication strategies stands as a very useful insight into the processes that may lead to L2 fossilization. These strategies are very familiar to language teachers and to anyone who has attempted, from adolescence, to learn a second or subsequent language. They are all contrivances, that make evident the participation of the conscious mind in the process of acquiring a second language, a mind familiar with the concept of system in language (L1) and aware that L2 must itself be systematic even if that system is only partially known or understood.

Bialystok distinguished between L1 and L2-based strategies, the former including the language switch, foreignizing, and transliteration. To the latter belong semantic continuity, description, and word coinage.

\subsection{Language switch}

Language switch occurs when the learner incorporates words and phrases from L1 into a target-language utterance.

(1) Hear loceng api, all go out!

Malay L1 loceng api (fire-alarm) + English L2

'When you hear the fire-bell, you must all go outside!'

This is an example of a widespread convention; the instruction is in English but it does not use the simple word 'fire-alarm' or 'fire-bell'.

(2) Kil ale skorei!

Tatar L1 kil ale (come please) + Russian L2 skorei (faster)

'Please come faster!' 
Tatar, belonging to the group of Turkic languages and spoken as the mother tongue mostly by Tatars who dwell on the territory of Russia, is in a rather asymmetrical relationship with Russian, which often results in fossilization both with Russian and Tatar speakers [10]. This often produces a variety of peculiar utterances which are usually understood by everybody, irrespective of their mother tongue.

Another good example of language switch is that of native-English speakers, expats living in Holland, who often use Dutch words to convey something which exists in English but has a context in Holland which is quite distinctive. The word 'zolder' is used to denote an attic, but whereas in England, the word 'attic' conveys a sort of a store-room under the eaves, perhaps entered by a drop-down ladder, in Holland it may be a furnished bedroom, a workroom, even a laundry, under the eaves, approached by a flight of stairs. So English speakers in Holland use 'zolder' even when speaking English to refer to that kind of attic. Another example would be the Russian word 'dacha' which is often used in English with reference to a little rural hideaway, a holiday home, not a permanent dwelling.

\subsection{Foreignizing}

In case of foreignizing the L1 language item stands for 'the creation of non-existent or contextually inappropriate target-language (L2) words by applying L2 morphology and / or phonology to L1 lexical items' [9, p. 10].

(3) Fingerpoken ist verboten!

English L1 + German ist verboten (is forbidden)

'Please do not poke fingers at...!'

Here 'Fingerpoken' is a mock-German word, devised from an English (L1) phrase 'poking fingers' - and given a German (L2) form, either for humorous reasons, as a warning to children or to make up for a genuine L2 deficiency. The words are English though 'finger' is also German — but put into a mock German verbal form.

(4) Kibette skidkalar barmy?

Tatar L2 kibette (in the shop), barmy (is / are there?) + Russian L1 skidka (discount) + plural Tatar suffix -lar

'Is there a discount in the shop?'

In an authentic Tatar utterance the word for discount would be in singular, so the Russian speaker is mistakenly putting the word that he / she does not know in a form that would be appropriate in Russian. Considering a great number of Russian loan-words in Tatar and numerous semantic doubles that emerged both from borrowing and translating words [11], this sounds quite a natural utterance even for a native Tatar-speaker.

\subsection{Transliteration}

Transliteration implies use of L2 lexis and structure to form a usually non-existent literal translation of an L1 word or phrase.

(5) Everybody please to wear their swimvest!

Here, an L1 German speaker 'anglicises' a German word 'Schwimmweste' to convey the actual English expression 'life-jacket'. 


\subsection{Semantic continuity}

Semantic continuity means use of a lexical item similar in meaning to the target item selected from the learner's limited L2 vocabulary - e.g. 'porte' (door) selected in lieu of 'barriere' - intended, but unknown — to refer to a gate into a field. It is a way of conveying something for which a specialised term exists but the speaker does not know it. Usually it works adequately and the interlocutor understands what is being described and may even provide the correct word.

\subsection{Word coinage}

Word coinage is an alternative to description comprising the word sense in a word or word combination of one's own.

(6) laveur de vêtements

This is coined in French (L2) for machine à laver (a washing machine).

\subsection{Description}

Description, or a descriptive circumlocution, is often used in the hope that the interlocutor will supply the appropriate missing word.

(7) a small machine ... electric ... very noisy ... to make small holes.

Until the interlocutor supplies the necessary word (i.e. an electric drill), the speaker is reduced to gestures, circumlocution and description. Description is a very widespread strategy in the classroom of upper-intermediate or advance learners who yet lack the knowledge of specific terms.

These strategies provide clear examples of fossilization. However, they help L2 learners not to avoid the topic or keep silent and thus enable them to stay involved in the communicative process. It is rational to use them, in this respect - though perhaps on the level of instrumental rationality, with a mere purpose of satisfying one's basic needs. If we conceive of knowledge not in terms of objective truth and success, but as a communicatively mediated concept, then rationality may be related to the capacity of speakers to reach an intersubjective recognition and understanding. In this case fossilization may be seen as an impediment, or not - depending on its extent. So long as L2 learners are understood, and treated the way they claim to be, the incorrectness of their grammatical constructions, their accent, or else the lack of fluency of their speech, as well as any other parlance shortcoming, should not be seen as a serious impediment to speaking out. According to the concept of communicative rationality, one, in all one's otherness, has equal rights with others to be respected and not discriminated against or excluded from the public sphere.

One the other hand, we might ask whether or not total native-speaker-like mastery of an L2 is a realistic expectation of adult L2 learners. Indeed, what most L2 learners want is to be able to communicate effectively, orally and verbally with L2 nativespeakers. But they are rarely expected to demonstrate language perfection if they learned the language in their post-childhood or in artificially created conditions of the classroom; their imperfections of lexis, grammar or pronunciation may well be part of their identity - what makes them distinctive, special. What matters is that communication is effective and understanding is secure. 


\section{CONCLUSION}

Rationality concerns people's ability to acquire and use fallible knowledge; from a linguistic perspective, a higher level rationality, consequently, may be thought of as overcoming one's fossilization. Ultimately, humans are learning beings. Apart from the advantages of total immersion into an L2 environment, modern means of education and communication may provide learners with alternatives. For example, linguistic corpora may help to eliminate learners' dependence on the teacher by exposing them directly to the naturally occurring language. Online language forums can also serve as a gateway to the world of target language speakers whose speech patters can be borrowed by L2 learners. In this respect, the concept of life learning may be seen as a framework for tackling fossilization, be it viewed as one's idiosyncrasy or an obstacle to mutual understanding.

In the search for answers - or at least greater clarity in understanding the problem of fossilization - it is clear that further careful research into the circumstances of L2 learning as a probable causal factor in fossilization is needed. It may well give us a clearer understanding as to why fossilization occurs and that may well enable us to better sequence the teaching of $\mathrm{L} 2$ to improve its reception and assimilation.

(C) Вавилова Ж.Е., Бродбент Дж.Т., 2018 Дата поступления: 1.06.2018

Дата приема в печать: 15.12.2018

\section{REFERENCES}

1. Selinker, L. (1972). Interlanguage. International Review of Applied Linguistics in Language Teaching, 10 (2), 209-232.

2. Han, Z.-H., \& Odlin, T. (2005). Studies of fossilization in second language acquisition. Multilingual Matters.

3. Trillo, J.R. (2009). Discourse markers. In J.L. Mey (Ed.) Concise Encyclopedia of Pragmatics (pp. 191-194). Elsevier.

4. Habermas, J. (2015). The Philosophical Discourse of Modernity. Twelve Lectures. Translated by Frederick Lawrence. John Wiley \& Sons.

5. Hymes, D. (1972). On communicative competence. In J.B. Pride, J. Holmes (Eds.) Sociolinguistics: Selected Readings. Harmondsworth: Penguin. pp. 269-293.

6. Shapira, R.G. (1978). The Non-Learning of English: Case Study of an Adult. In E. Hatch (Ed.) Second Language Acquisition (pp. 246-255). Rowley, MA: Newbury House.

7. Green, M. (2007). Speech Acts. Stanford Encyclopedia of Philosophy. Retrieved April 14, 2018. URL: https://plato.stanford.edu/entries/speech-acts/.

8. Wang, J. (2011). Impacts of Second Language Classroom Instruction on IL Fossilization. Journal of Cambridge Studies, 6 (1), 57-75.

9. Bialystock, E. (1980). Oral communication strategies for lexical difficulties. In Interlanguage Studies Bulletin, 5 (1), 3-30.

10. Broadbent, J.T., \& Vavilova, Zh. (2015). Bilingual identity: issues of self-identification of bilinguals in Malaysia and Tatarstan. In 3L: Language, Linguistics and Literature. The Southeast Asian Journal of English Language Studies, 21 (3), 141-150.

11. Galieva, A., Vavilova, Zh., \& Gafarova, V. (2017). Developing Tatar Corpus-Based Dictionaries for Educational Purposes. In 11th International Technology, Education and Development Conference INTED-2017 Proceedings (pp. 9014-9022). Spain, Valencia: Inted. 


\title{
ФОССИЛИЗАЦИЯ, КОММУНИКАТИВНАЯ РАЦИОНАЛЬНОСТЬ И КОММУНИКАЦИОННЫЕ СТРАТЕГИИ В ОБУЧЕНИИ ИНОСТРАННОМУ ЯЗЫКУ
}

\author{
Ж.Е. Вавилова ${ }^{1}$, Дж.Т. Бродбент ${ }^{2}$ \\ ${ }^{1}$ Казанский государственный энергетический университет, Казань, РФ \\ Ул. Красносельская, 51, Казань, Республика Татарстан, РФ, 420034 \\ ${ }^{2}$ Центр языковой подготовки «PEAR Academy» \\ Австралия, Аделаида, Уровень 2/127 Rundle Mall, SA5000 \\ Level 2/127 Rundle Mall, Adelaide SA5000
}

Фоссилизация была впервые определена в 1972 году как неудача или окончательная остановка в освоении иностранного языка взрослыми обучающимися, которая не соответствует компетенции носителей языка. Она представляет собой заключительный этап в речевом развитии индивида и характеризует большинство попыток изучить иностранный язык в зрелом возрасте.

За 40 лет с момента возникновения термина «фоссилизация» в освоении иностранного языка взрослыми получила широкое признание в научных кругах как подлинно существующее явление. Теперь она рассматривается в качестве феномена постоянного и устойчивого к коррекции как посредством целенаправленного обучения, так и под влиянием аккультурации. Однако до сих пор не выработано общепризнанного определения или объяснения механизма фоссилизации.

В статье предпринята попытка рассмотреть фоссилизацию и ее возможный исход в коммуникативной практике взрослых обучающихся с экстралингвистической точки зрения, опираясь на языкознание и теорию и практику преподавания языков, с одной стороны, и философией коммуникации - с другой. Применяется концепция коммуникативной рациональности Ю. Хабермаса: в работе демонстрируется, как совершенствование навыков ораторского искусства и письменной речи обеспечивает коммуниканту более значимую роль в диалоге, что представляется достаточным основанием для того, чтобы стремиться преодолеть фоссилизацию.

С точки зрения теории речевых актов в статье предпринята попытка проследить механизм фоссилизации при переходе из внутреннего пространства индивидуального сознания и интенции (иллокуции) во внешнее пространство перлокуции, когда локутивное искажение речи не влияет на намерения говорящего и он не получает реакции о сделанной ошибке. Рассматриваются некоторые факторы, препятствующие эффективности подобной коррекции, а также ряд стратегий, применяемых обучающимися в коммуникативном процессе.

Ключевые слова: фоссилизация, изучение иностранного языка, коммуникативная рациональность, коммуникационные стратегии, теория речевых актов

\section{Для цитирования:}

Вавилова Ж.Е., Бродбент Дж.Т. Фоссилизация, коммуникативная рациональность и коммуникационные стратегии в обучении иностранному языку // Вестник Российского университета дружбы народов. Серия: Теория языка. Семиотика. Семантика. Т. 10. № 2. С. 522-531. doi: 10.22363/2313-2299-2019-10-2-522-531.

\section{For citation:}

Vavilova, Zh.E., Broadbent, J.T. (2019). Fossilization, communicative rationality and communication strategies in second language learning. RUDN Journal of Language Studies, Semiotics and Semantics, 10 (2), 522 - 531. doi: 10.22363/2313-2299-2019-10-2-522-531. 


\section{Сведения об авторах:}

Вавилова Жанна Евгеньевна, старший преподаватель кафедры философии и медиакоммуникаций Казанского государственного энергетического университета; научныле интересы: компьютерно-опосредованная коммуникация в философской интерпретации; модели и средства мультимодального синтеза текстов для интеллектуальных обучающих систем; теоретические аспекты управления стратегическими коммуникациями; e-mail: zhannavavilova@mail.ru

Джон Тейлор Бродбент, консультант центра языковой подготовки «PEAR Academy»; e-mail: johntaylorbrdbnt@hotmail.com

\section{Information about the authors:}

Zhanna Evgenievna Vavilova, senior lecturer, Department of Philosophy and Media Communications, Kazan State Energy University; research interests: computer-mediated communication in philosophical interpretation; models and means of multimodal text synthesis for intelligent learning systems; theoretical aspects of strategic communications management; e-mail: zhannavavilova@mail.ru

John Taylor Broadbent, consultant, language training center "PEAR Academy"; e-mail: johntaylorbrdbnt@hotmail.com 